\title{
Reconfiguring Ottoman Gender Boundaries and Sexual Categories by the mid-19th century
}

\author{
İrem ÖZGÖREN KINLI \\ İzmir University of Economics, Turquía \\ iremozg@yahoo.com
}

Recibido: 10-09-2012

Aceptado: 19-12-2012

\begin{abstract}
This research extends the theory of the civilizing process of Norbert Elias to the gender issue in the Ottoman Empire and thereby in some respects provides a test of his original theory. This study is based on the assumption that the conscious policy of the Ottoman modernization by the ruling elite exhibited many symptoms resembling those of the European civilizing process. The socio-historical process of bureaucratization of the Ottoman state fostered the changes in manners and forms of cultural expression which brought with it the advance of the threshold of shame and embarrassment in gender relations during this process. Drawing on this assumption, the article looks at the changes in the way people control themselves and others in the expression of their impulses and emotions. In turn, - the question of how the margins of tolerance in sexual matters and in the expression of emotions and desires changed during this civilizing process - formulates the major concern of this paper. Since manuals on etiquette, manners books, diaries and archives are the richest sources for this purpose, this project employs the analysis of these cultural texts, in order to make inferences from the cultural transformations within the Ottoman Empire. The research hopes to offer new perspectives in reorienting the way we look at the development of the Ottoman culture within the context of figurational sociology.
\end{abstract}

Key words: Gender, Ottoman Empire, civilizing process, Norbert Elias, sexual categories.

\section{Referencia normalizada}

Özgören Kinli, Í. (2013). "Reconfiguring Ottoman Gender Boundaries and Sexual Categories by the mid-19th century”. Política y Sociedad, Vol.50 Núm 2: 381-395

Sumario: Introduction. 1. Literary representation of explicit sexual discourse and blurring gender boundaries. 2. Changes in the threshold of shame and embarrassment in the discourse of gender relations. 3. Conclusion. 


\section{Introduction}

Norbert Elias is best known for his book, The Civilizing Process, originally published in German in 1939, wherein he traces most fully the connection between the personality structure of people and the structure of relationships in society at large. By analyzing books about manners that had been published between the thirteenth and eighteenth centuries, Elias observed changing emotional economy of the personality and the gradually growing calculability of social existence brought about by long-term processes of change in the structure of societies. In this sense, The Civilizing Process is also a study of the changing codes of manners and standards of social behavior which broadly accompanied long-term processes of social development in European history.

Considering several difficult conceptual and methodological problems arising at the outset in any attempt to use and test the theory of civilizing process in a largescale and long-term cross-cultural context (Mennell, 2003), this article explores the ways for extending the theory of the civilizing process based entirely on European evidence for examining the changing dynamics of the Ottoman history. The main argument of this paper is that the concept of the civilizing process offers a theoretical framework for understanding the reasons of the changes in the Ottoman court elite's sensibilities and sensitivity regarding morality, desire, sexuality, and homoeroticism, taking into consideration certain limitations in the absence of any real challenge to the power of central authority, in the disappearance of a prosperous, enterprising bourgeoisie and court aristocracy for the transmission and standardization of these changes to spread throughout the Ottoman society as it had in Europe. From this perspective, this article challenges the way Ottoman society has moved from an emotional level to a more controlled use of expression, and attempts to explain the reasons of this transformation.

This article takes an Eliasian perspective on the process of bureaucratic centralization of the Ottoman Empire in the mid-nineteenth century in which the unique category of homosexuality and heterosexuality, imported from European laws, changed the existing Ottoman gender boundaries and sexual categories. This research raises and discusses the question to what extent this change in the social regulation of sexuality corresponded to a change in emotion regulation, the regulation of sexual longings and emotions in particular. It claims that these administrative changes originated from shifts in the balance of power between Ottoman military and civil elites and led to a profound transformation of categories of gender, new balance of desires, powers and tensions between women and men. As a result of bureaucratic reforms, homosexual practices lost any public legitimacy by appearing in the guise of the homosociality.

This paper examines the political reasons and the cultural consequences of rejecting the existing system based on multiple sexuality discourses and of introducing heteronormativity as a dominant norm to the Ottoman Empire. It appears that this was a highly problematic issue because of the (in)ability of an adaptation to the new sexual codes in the Ottoman context. The question of - how 
and to what extent the adoption of Western heteronormative regime has generated a new sense of shame or embarrassment threshold for sexual matters - formulates the major concern of examination.

This study employs the analysis of cultural texts including archives and legal codes being the richest sources for making inferences about cultural transformations within the Ottoman Empire. Ottoman manuals of etiquette and manner books are also valuable sources of research because they provide information on changes in behavior, sensitivities and rules governing the allowed range of behaviors, prescribed and / or prohibited. In addition, they offer empirical evidence in relation to the evolution of the individual and its relations with groups in the way of selfregulation.

In the first place, Ottoman erotic literature is very useful to address the question of whether the sexual drives were gradually seen as shameful and embarrassing in the Empire. In the second part, we analyze the various transformations that have taken place in gender relations due to the historicizing of changes in the threshold of shame and regulation of sexual impulses. Herein, we propose to study the possibility of applying Elias' observation in early modern Europe about a growing secrecy and concealment of sexual activities concomitant with a more general rising threshold of shame concerning the body, its functions and display, in the case of the Ottoman civilizing process.

\section{Literary representation of explicit sexual discourse and blurring gender boundaries}

Drawing on Elias' assumptions about the history of manners, this research looks at the changes in the way people control themselves and others in the expression of their impulses and emotions. This paper plans firstly to explore whether the claims of Elias (1982, p. 146) that "the feeling of shame surrounding human sexual relations ... changed considerably in the process of civilization" are applicable in the case of the Ottoman Empire.

Bardakçı's, Erdoğan's and Andrews's \& Kalpaklı's studies are well equipped to answer the question whether sexual drives were gradually perceived as shameful and embarrassing in the Ottoman Empire. Bardakçı (1992) provides us with transcriptions of many primary sources regarding the sex in the Ottoman Empire, arguing that there was more sexual tolerance in the pre-modern Ottoman society. In presenting a number of collected texts on the Ottoman period, on homosexuality, on sex humor, on sexuality, Erdoğan's (1996) The sexual life of the Ottoman Society shows that there was no sanction on the publication or distribution of these sexual materials in the Empire until the middle of the nineteenth century. In addition to sampling representations of sex, gender and pleasure in classical Ottoman lyric 
poetry ${ }^{1}$ and prose, it is appropriate that we mention The Age of Beloveds, which was written by Andrews and Kalpaklı (2005). This study investigates the prevalence of homosexuality in Ottoman society by focusing on a specific period $\left(15^{\text {th }}\right.$ and $16^{\text {th }}$ centuries). Authors argue that male homoeroticism, which reproduces male pleasure and gaze, was a common phenomenon among Ottoman court elites.

This does not imply that these acts of sexual practices were not prohibited or not punished by the religious authorities. On the contrary, in some cases, these acts were punished severely. Yet, punishment does not show that these acts were considered as deviant, abnormal, or unnatural. This is made clear even by the fact that most authors of the manner books were themselves members of the religious establishment.

In view of the fact that sexual discourse in the pre-modern Ottoman world was rich and varied, it is natural that its manifestations were to be found in literature and poetry. There are multiple sources that inform us about the sexual life of Ottoman men and women; however we rarely encounter major works which directly address the Ottoman sexual discourses. One of the most interesting exceptions is a sixteenth century work of erotic prose, Mehmed Gazali's ${ }^{2}$ Dafi'ul gumum ve rafi'ul humum [which means the book repels sorrow and removes anxiety] dealing explicitly with the theme of sexuality. As admitted by to the close circle of Prince Korkud in Manisa Palace, it is assumed that Mehmed Gazali wrote this manuscript as a humorous work, primarily for the entertainment of the courtiers. The following description of the content of this manuscript draw attention to Elias' argument in The Civilizing Process that in earlier centuries such matters were spoken of frankly without shame, seems to be true not only for Europe, but also for the Ottoman Empire.

The first chapter of Gazali's book entitled, The Virtues of Marriage, begins with the concerns of the origins of adultery and emphasizes marriage as a form of union that protects men against sinful liaisons. However, the chapter ends with a strong denial of marriage, shown here to be a limiting relationship for free men. The second chapter displays an allegoric dispute between boy-lovers and woman-lovers, who were described in the text as "pederasts" 3 and womanizers. In the third chapter, there is a classification of "pederasts" on the basis of their choice of beloveds (whether they prefer youngsters or adults). There is a catalogue of postures applicable in male-to-male sex. Many stories told in the book take place in various contexts. In the fourth chapter, author tells the stories of dissatisfied women having

\footnotetext{
${ }^{1}$ See especially the collection of poems edited by Bingölçe (2007) about sexuality that were written to please the Ottoman elites.

${ }^{2}$ Whose pen name is Deli Birader (Crazy Brother) was a well-educated cleric during the reign of Sultan Bayezid II.

${ }^{3}$ In the original text of the manuscript, the term «oğlancı » (pederast) is used as a pejorative term.
} 
sexual relations with their lovers, and masturbating with dildos. The main topic in the fifth chapter is masturbation, nocturnal emission and bestiality. The author includes stories about self-eroticism and intercourse with various animals from elephant to louse. He furnishes us with a mock-vocabulary of masturbation techniques. The main topic in the sixth chapter is effeminate homosexuals. In this chapter, Gazali develops a pseudo-scientific explanation about the cause of, what was described as, passive homosexuality. The last chapter offers detailed descriptions of the profession of pimping. ${ }^{4}$

Certainly, an interest in sodomy, especially as a source of humor, does not represent the Ottoman government's official policy towards homosexuals. The following manual of etiquette, Tables of delicacies concerning the rules of social gatherings, which was written during the same period for the purpose of giving instruction in proper conduct in 1599-1600 by the Ottoman bureaucrat and historian Mustafa Ali illustrates the Empire's formal approach. On the one hand, in one section of the manuscript, sex with 'beardless youth' mentioned as disgraceful; on the other hand, -in another section of the manuscript- these 'beardless youth' are "praised for their sensuous qualities". Under these circumstances, explanations of the basic characteristics of "lads who can be objects of desire by lovers" and employment of an "extensive jargon about homosexuality" in the manuscript can be interpreted as the evidence of that there was an existence of widespread homosexuality (Broukes, 2003).

The quotation from this etiquette book explains the reasons for the prevalence of sodomy states that: "There are more dishonorable men who prefer beardless, smooth-cheeked, handsome and sweet-tempered servant boys than there are men who prefer pretty and charming women. This is because marriageable women from among the ranks of beauties are maintained in secret, out of fear of the police." (Broukes 2003, p. 28). In terms of sexual morality, his point is that "the proper gentlemen" will carry out their activities "in private", and with "extreme discretion" to "refrain from public display of homosexuality." (Broukes, 2003). ${ }^{5}$

${ }^{4}$ For the presentation of an annotated translation of this book, it is indispensable to consult Kuru's (2000) Ph.D. Thesis. It would also be better to consult an abridged English translation of this manuscript: Landor (2001).

${ }^{5}$ We should mention herein the work of Malti-Douglas, which studies the role of women in classical and modern Arabic literature. According to Malti-Douglas (1991), this literature expresses a fear of female sexuality which results in the preference of males for the company of their gender. Women are thus marginalized, while men prefer the homo-social bonds, leading necessarily homosexuality. We should also mention Bouhdiba's (2007) classical work Sexuality in Islam which perceives sexuality in the history of the Islamic world as a tragedy in which the stage is occupied by homosexuality derived from a denial of the feminine element to the place it deserves. 
Yet, a book of manners called Risale-i Garibe [The Treatise of the Weird booklet], demonstrates that sexuality was a natural part of everyday life during the course of the late seventeenth century. Risale-i Garibe is one of the most useful sources on Ottoman society with detailed information on various classes, occupations, ethnic and religious groups, on appropriate manners of the proper Ottoman elite. In this manuscript, we see no hints indicating that conducting sexual intercourse with prostitutes was in itself a forbidden or an ill-mannered practice. In fact, this text shows that prostitutes and brothels were ordinary part of everyday life. It also contains some evidence that for an Ottoman man it was not unusual to experience both passive and active homosexuality and it is observed that homosexuality was a common phenomenon used liberally in the text (Develi, $1998)^{6}$.

Of great importance for the light they shed on the Ottoman history, memoirs of the Ottoman court, entitled Tarih-i Enderun, Letaif-i Enderun [History of the Ottoman palace school] by Hizır Ilyas Aga, who had received his education in the Enderun [The Ottoman palace school] between 1812 and 1830 at the court of Mahmud II. From this work we learn that homosexuality is accepted as normal in the Ottoman court school (Kayra, 1987).

In an obvious manner, by the mid-nineteenth century, bahnames [sex guides or book of sexology $]^{7}$ containing recipes for aphrodisiacs, recommendations for sexual health, contraceptive measures, and positions of sexual intercourse which have a long history in eastern cultures have virtually disappeared. Authors no longer wrote these guidebooks, or did not dare to publish them.

In this regard, we argue that open discussion of sexuality disappeared or was weakened to the extent that it practically vanished during the nineteenth century. Taking all these sources into account, it is time to consider why open discussion of sexuality in Ottoman society in the early modern period disappeared, at least from public view, during the nineteenth century (see Ze'evi). Drawing on Elias' description of the changes in psychology and social behavior caused by the necessity of adapting to new forms of social life, we can move on to analyzing the reasons of 'gradual removal of sexuality behind the scenes' in the Ottoman Empire. ${ }^{8}$ By following Elias, we will attempt to demonstrate, in the following, that

${ }^{6}$ Author defines male homosexuality in the book with terms such as i.e. p. 24: cüvan, nigar; p. 31: gulampare; p. 27: hiz; p. 37: kekez; p. 25: kulanpara; p. 25: muglim...etc. which have no more counterparts in contemporary Turkish language. The disappearance of these different words on homosexuality gives us some hints for the fact that the open discourse on homosexuality does not exist anymore in public space.

${ }^{7}$ According Uzel (2005, pp.7-9), there are 51 manuscripts ottomans as they can be classified under the title of bahnames (sex guides).

${ }^{8}$ It would be a great oversight to omit to mention herein Ze'evi’s (2006) original book, Producing Desire. This book provides some clues about the reasons for changing attitudes toward sexuality in the Ottoman Empire. Firstly, the struggle for hegemony between the 
"previously open discourse on erotic attachment and passionate love" in the Ottoman Empire "was silenced by” the civilizing process (Ze'evi). ${ }^{9}$

\section{Changes in the threshold of shame and embarrassment in the discourse of gender relations}

According to the well-known basic idea of figurational sociology, societies are composed of ever-changing networks of mutually interdependent individuals which form figurations with one another (Elias 1978, p. 128). Elias argues that these individuals in groups have their own dynamics while participating and forming figurations. From this angle, power is a dynamic element that structures respective figurations. Thus, figurational approach is depicted through the term of "balance of power". Elias demonstrates the ways of shifting the tensions by presenting of " $a$ balance of power moving to and fro, inclining first to one side and then to the other" (Elias 1978, p. 131).

The figurational sociologist Elias (1987) contends that the change in the balance of power between the sexes which took place in the development of Roman society was not initially the outcome of a planned change of legislation. In contrast, it was originally a change of custom that testifies an extensive transformation of society as a whole. At this point, as we will see in the rest of this article, this statement is not verifiable in the Ottoman case since the balance of power between genders came out firstly by a radical transformation in the Ottoman legal system which accompanied though more latterly changes in custom.

Another methodological problem that arises is the fundamental difficulty of the application of the Eliasian conceptualization in the case of the Ottoman political system including the social structure and its economic bases. Building on his research on gender relations, Elias identifies the gradual accumulation of great wealth in the hands of the aristocratic families of Rome as an underlying cause of a change in the husband-wife relationships in Roman society. In contrast to Roman society, it is not possible to detect neither aristocratic nor noble classes in the Ottoman Empire. Under these circumstances, the transition of women's situation in

orthodox ulema and the heterodox Sufi orders brought about a profound reduction in the tolerance of the governing authorities toward sexual practices. Secondly and herein lies his main argument, the new conceptions of sex and power in the West brought about changes in the sexual orientations of the Ottoman Empire. It should be emphasized here the importance of his argument, p.165: "Changes in sexual discourse...came about...as a result of sweeping social and political changes" whereas in the "Ottoman world the process was reversed. Changes in sexual discourse preceded changes in society and politics."

${ }^{9}$ Herein, Ze'evi argues that this open sexual discourse in the Middle East was silenced by modernity. We prefer to define this process as "civilizing" instead of the term of modernity. 
the Roman society from being husband's property to being the owner of property is not testable in the Ottoman case.

Yet we assume the fact that Eliasian conceptualization would be still useful for reconfiguring Ottoman gender boundaries and sexual categories by the mid- $19^{\text {th }}$ century. In figurational sociology, relationships between men and women, like all other social bonds, depends crucially on the character and the general structure of the society where they live in. The type of economy, the level of economic development, warrior or peaceful character of inter-societal relations and the positioning of the society vis-à-vis the others are particularly important in order to explore gender relations. According to Elias (1987), it is indispensable to take into consideration the changing dynamics of a society for understanding the shifts of the balance of power between the genders. In short, overall social changes in the balances of power between genders occur considerably over long-term periods of time and / or generations. In this sense, we explore the changing balance of power between genders in the Ottoman Empire throughout its long-lasting history in reference to Elias' figurational sociology and his term, balance of power.

From the figurational sociology perspective, it is not surprising then to observe the hegemony of men over women in Ottoman society where the warrior values, physical strength, courage, heroism, defense and security were praised. In this male dominant society, there was a hidden presence of women due to religious restrictions. Moreover, the public expression of love for a woman was impossible in this social universe; therefore a kind of affection that can better be addressed publicly was the one between men. Thus, there was an amplification effect of male homoeroticism in public discourse, a scarcity of similar material on the subject of women homoerotic relationships and an illusion of a more generalized homoeroticism than it would be in real life. Under these circumstances, the most interactive and commonly observed relationship was the man to man in a society which is a fundamentally phallocratic one.

We argue that it is possible to define the perception of the woman in the Ottoman context by making reference to Laqueur's (1992) one-sex model : “woman is as an imperfect version of man, and her anatomy and physiology were construed accordingly: the vagina as an interior penis, the womb as a scrotum, and the ovaries as testicles. The body was thus a representation, not the foundation, of social gender."

From this perspective, we can highlight the futility of the notion of indulgence toward homosexuality, which, anyway, was never designed as a separate issue and men and women were biologically perceived as variations of the same sex. ${ }^{10}$ Ideas of beauty were ungendered; and men were attracted to other men for the lack of intellectual, spiritual or moral affinity in their relationships with particularly poorly educated women compared to men.

${ }^{10}$ For the objections to the “one-sex model”, see especially Ze'evi (2006, p. 22). 
In the Ottoman Empire, writing poems to a generally or normally beardless boy (adolescent youth who is desired by his male counterparts) ${ }^{11}$, with a declaration of love in public or in private, was a fully engaged, even admitted, practice among many of these religious authorities even though they condemned more or less severely, sex between men. ${ }^{12}$ Despite the tensions between orthodox and heterodox Sufi elite leaders, the homoerotic discourse remained and described as a natural and an accepted social reality in the Ottoman Empire until the nineteenth century.

There was a sexual classification of men according to their passive or active role, not by their gender partners. At the dawn of the nineteenth century, the Sufis, as a whole, internalized a strong rejection of homoerotic traditions. In the meantime, references to the love of boys disappeared in the Ottoman literature; they became routinely be interpreted as mere allegorical expressions of the love of God.

In the Ottoman case, gender was not reduced to the dichotomized categories of male and female, and other gender categories were recognized on their own ground. Homosexuality was not the shameful act, but the fact of showing off, was blamed and punished in the Ottoman context. References to the homosexuality and the hermaphrodity in the Ottoman laws underline the fact that heterosexuality was not the only type of gender relations commonly observed in the Ottoman society:

For a legal cohabitation, it is necessary for the wife to be a woman. Marriage is a union between a man and a woman. Therefore, marriage of a man with a man or a hermaphrodite does not exist. The marriage of a hermaphrodite with a man or a woman or with another hermaphrodite remains unresolved, as sex is not determined in a clear manner.” (Young 1905, pp. 210-214).

It is reasonable to assume at this point that the level of effective monopolistic control of physical force that the Ottoman state is able to maintain will likely have a significant influence on the balance of power that develops between the sexes. The specific form and character of gender relations and gender identities, the values and ideologies about gender relations, will depend in part on the specific trajectory of this society during the civilizing process and the level it has reached. It is in this context that we analyze the relationship between changes of the Ottoman state structure and gender categories with a figurational approach.

With the emergence of the modern Ottoman bureaucracy in the nineteenth century, the rulers of the Ottoman Empire modified the laws so as to adapt it to their needs and values and created a new corpus of legal texts by fixing Europe as a reference point for the "modernization" project. While increasing awareness of the Western type of sexual relationships, which favors heterosexuality, in their

${ }^{11}$ Further works can explore the dynamics of class privilege and age difference that can dominate the desiring affairs between men and adolescent boys in the Ottoman context.

${ }^{12}$ It has been always difficult to detect the recipient of fictitious love in poems since Turkish language ignores all kind of gender distinctions and the notion of androgyny makes sense in this context. 
development, the Ottoman elites repressed commonly observed homosexuality. The attenuation of differences between men and women as far as legal status and punishment proved the fact that the balance of power between the sexes had shifted in women's favor in the Ottoman civilizing process, as it had in the West.

"Another look" of the Europeans with whom the meeting and confrontation were formed and intensified in the nineteenth century, which then transformed the vision of the Ottomans themselves and blamed the cult of youths, as well as some crossdressing men as women in certain festive occasions, for example. The binary gender became the rule, the beauty feminized. At this stage of our argument, we propose to analyze the process of bipolarization of the gender which took place in the Ottoman laws of nineteenth century.

We suggest that the development of the codification of laws regulating and controlling sexuality by the middle of the nineteenth century in the Ottoman case might be the clearest illustration of the "threshold of shame as a control mechanism of the civilizing process". We argue, from an Eliasian perspective, that there had been a "gradual removal of sexuality behind the scenes of social life", reflecting the "advancing threshold of shame and embarrassment" and "shift in the balance of external and internal controls”.

In order to realize the modifications of the regulation of laws related to sexuality in the Ottoman civilizing process, it is indispensable to take into consideration Tanzimat codifications derived from the French, Swiss and Belgian legal systems in the nineteenth century (see Bozkurt, 1996; Belgesay, 1999; Velidedeoğlu, 1999; Imber, 2004; Rubin, 2007). But previous to this, we should put, firstly, emphasis on the set of laws, called the Kanun, which was codified by the Sultan Suleyman in the sixteenth century (see İnalc1k, 1993) and secondly, Ottoman code of laws, collated by İbrahim Halebi, which remained the foundation of Ottoman law until the reforms of the nineteenth century.

The Kanun of the sixteenth century during the reign of Sultan Suleyman appears to be less severe than that of Islamic law in its punishments against adultery, but provides applicable and effective penalties, while Islamic law prescribes very severe punishments for some sexual offenses. Herein, we should emphasize the fact that even though same-sex intercourse is considered as a violation of Islamic Penal law, there are different opinions for this infraction among religious authorities for the types of penalties that should be imposed by sharia law. (see Chebel, 2002; ElRouayheb, 2005; Najmabadi, 2005). Furthermore, the punishment for same-sex intercourse was "in most cases left undetermined" (Ze’evi, p. 55).

Unlawful intercourse was defined in religious law, as all acts of sexual penetration other than those between a married couple or a master and his female slave. Adultery is a crime enacted specifically by Islamic law that requires severe punishment, such as flogging or execution by stoning, depending on the status of perpetrator. Regarding to the Ottoman legal system, the Ottoman Kanun imposes a great variety of alternative penalties, primarily fines. The criminal code of Sultan Suleyman determines the different types of fines for committing adultery according to the social status (wealthy or not) and to the sexual status (virgin or not) of the 
perpetrator. Concisely, the Ottoman code designates monetary fines for fornication while excluding execution as a penalty for this crime.

Until the nineteenth century, the Ottoman Empire was governed by the code of laws called Multeka, founded on the precepts of the Quran, the oral laws of the prophet, his practices or his opinions; together with the rulings and decisions of the early caliphs. This work was translated into Turkish during the reign of Mehmet IV (1642-1693) and delivered to kadis (Ottoman judges) as a semi-official OttomanCode in order to practice in jurisdictions. The code Multeka consisted of legal regulations about religious, civil, criminal, political, and military affairs.

This code, considered as paramount law, regulated all aspects of sexual matters in great detail, including issues ranging from fornication, to same-sex relations, to pederasty, to rights of hermaphrodites, and to animal rapes. Regarding to codifications with reference to European legislations, by the mid-nineteenth century, we observe a kind of a neglect of the details of these issues related to sexuality. Besides, a notice of concern among Ottoman elites was designed to provide the equality between men and women before the law.

It seems reasonable to assume herein that the small but significant shift in the balance of power between men and women was realized in 1858 by the Ottoman adaptation of the Napoleonic Code, in this complex, multifaceted and not simply linear process. This code promulgated by the Sultan Abdulmecid, and inspired by the European legal codes by the new Ottoman elites of the nineteenth century who were actually interacting with European culture, reduced the differences between men and women, while it abolished any distinction between free and slave, between Muslim and non-Muslim (Taner, 1999).

For example, article 43 of this Ottoman Penal Code of 1858 regarding the changing relationships between men and women states that: "There is no difference between the two sexes as to legal punishment, but for women, we must, in the implementation of certain penalties, take into account women's special conditions". (Young 1906, pp. 8-9).This seems to be an attempt by the elite, -at least-, to improve the condition of women compared to men before the law. However, if we go through article 188 of the Ottoman Penal Code, which deal with honor killings, we see that men who had punished unfaithful women harshly were not penalized. This article states that: "He who has seen his wife or any of his immediate female relatives with a man committing adultery, he may beat, injure, or kill one or both of them, in these cases, he will be exempt from penalty." (Young 1906, p. 37).

The Penal Code worked as a form of bracketing of sexuality. Sexual crimes were being euphemized in indecent acts and the code chose to remain silent on all issues concerning the relations of various genders in order to regulate the new criteria of shame in the Ottoman society. This Code may show us the attempts of the Ottoman elite to mobilize the right to the definition of modesty under the category of indecent assault. Abduction and rape were described as a criminal offence against the family rights and were considered as an insult to the family's reputation. The articles of the 1858 Ottoman Penal Code concerning sexual offences were incorporated into the chapter on crimes against honor. 
The articles in this chapter heading "attacks on morality" discuss, in detail, various punishment types for an attack on the modesty of a child under the age of 11 (article 197), for violent attacks on modesty (article 198), for perpetrator in a position of authority over the victim (article 199), for the rape of unmarried girls (article 200), for provoking of youth to debauchery and fornication (article 201), for outraging public decency (article 202), for fraud or kidnapping by violence a child who has not attained the age of puberty (article 206) (Young 1906, pp. 38-40).

While this new legal structure introduced a more detailed set of punishments for sex-related violence, it completely ignored issues such as pederasty, same-sex relations and bestiality. In this way, consideration of sexual diversity in Ottoman society was limited by legal regulations in the civilizing process. Thus, classification of issues of sex and sexuality under the heading of crimes of honor in this Ottoman penal code, which was based on French model of 1810, supports the claims of Elias that sexuality had come to be more strongly associated with shame and embarrassment in the Civilizing Process.

This self-censorship in Ottoman sexual discourses continued with the Mecelle code, the civil code of the Ottoman Empire in the late nineteenth and early twentieth centuries, which was clearly influenced by the earlier European codifications in its structure and approach. The concept of an official code in the sense of European legal terminology was introduced into the Ottoman Empire in the nineteenth century. Thus, the Ottoman modern bureaucracy in the nineteenth century had become an upper-level society with its new legal structure, which attempted to regulate and control sexuality, reinforcing the norm of heterosexual relations through these massive sociopolitical changes.

It is significant to note that the Ottoman Civil Code of $1869^{13}$, Mecelle, including 1851 articles and 16 volumes, left the marriage as a provision intact. The code was prepared by a commission headed by Ahmet Cevdet Pasha, published from 1869 to 1876 and came into force in 1877. Its structure was clearly influenced by European codifications. It covers most areas of civil law, but law has exempted the family. Acts relating to civil marriage, divorce, inheritance and child custody were enacted by the Law of Family rights in 1917. The adoption of this new codification can be interpreted as an other initiative of Ottoman elites for shifting dramatically the balance of power between the sexes tilted in favor of women (Bouvat, pp. 5-26).

${ }^{13}$ For discussions on the process of preparing the Code, see Velidedeoğlu (1968, pp. 710-718). 


\section{Conclusion}

The examination of emotions and passions that determine the rules of conduct in a social environment shed light on the ways how groups adapted themselves to manners. It is within the framework of analysis that we observe various emotional manifestations among the upper social strata. We notice that the Ottoman elites were, in general, much more spontaneous and free in the expression of desire before the nineteenth century. The observation of these elites' sex manners enables us to describe both the ancient uses of body and the rise of sensitivities relating to bodily functions in the process of Ottoman civilization.

It was not until the nineteenth century that the Ottoman Empire unties the question of desire from physical impulses and gradually creates a mental pattern. Any homosexual practice is therefore hidden, kept secret or loses any public legitimacy; it lives under the guise of homo-sociality. Marriage, once seen as a simple procreation contract, becomes the union of men and women treated more fairly balanced by the laws of the nineteenth century and the center of the only legitimate sexual relations, dedicating the single register of heterosexuality.

This system of multiple sexualities, notably the status of homoeroticism and its social and discursive constructions, appears so suddenly faced with a binary model of Western modernity. It seems clear that the class of unambiguous homosexuality and heterosexuality, imported by European laws, changed the discourse of multiple genders in the process of bureaucratic centralization of the Empire. We find that this process contributed to the removal of the male beloved from the discourse of desire and that led to a profound transformation of the categories of gender, a new balance of desires, powers and tensions between the two sexes, and a restructuring of male domination. European sensibilities projected heterosexual desires through the depiction of woman as the object of sexual longing and transformed same-sex desires into an abject practice in the Ottoman case.

It is clear that the adoption of a strict hetero-normative or even radical scheme is seen as the effect of imposition by the West for new sexual norms in the wake of political, administrative and cultural reforms of the Ottoman state. The historicization of mutations of the categories of gender in the Ottoman world moves for that very reason its cultural categories, its boundaries and its specific periodization. The male homoeroticism is seen later sublimated into the national fraternity, in the bond of brotherhood and nationalistic citizenship, so it remains lawful for two men to walk hand in hand, because it refers to fiction of a homosociality detached from any sexuality.

We can conclude by arguing that while it is possible to analyze gender relations in the Ottoman society according to Elias' theoretical framework, many limitations of the Ottoman society described here inevitably led to a dissimilar civilizing process from the European one, which shows that his model may not be completely applicable to the Ottoman society, but it has much to offer us to understand the Ottoman civilizing process. This paper hopes to offer new perspectives in 
reorienting the way we look at the development of the Ottoman culture within the context of figurational sociology.

\section{References}

Andrews, W. and Kalpakli, M. (2005): The Age of Beloveds: Love and the Beloved in Early Modern Ottoman and European Culture and Society, Durham, Duke University Press.

Bardakçi, M. (1992): Osmanlı'da seks: Sarayda gece dersleri, İstanbul, Gür Yayınlar1.

Belgesay, M. R. (1999): “Tanzimat ve Adliye Teşkilatı”, in Tanzimat, vol. 1: 211220, İstanbul, Milli Eğitim Bakanlığı Yayınları.

Bingölçe, F. (Ed.), (2007): Galip Paşa. Mutayebat-ı Türkiyye. Türkçe eğlencelikler, Ankara, Altüst Yayınları.

Bouhdiba, A. (2007): Sexuality in Islam, London, Routledge.

Bouvat, L. (1921): "Le code familial ottoman de 1917" in Revue du monde musulman 43: pp. 5-26.

Bozkurt, G. (1996): Batı Hukukunun Türkiye'de Benimsenmesi, Ankara, Türk Tarih Kurumu.

Broukes, D. S. (Ed.), (2003): The Ottoman Gentleman of the Sixteenth Century. XVI. Yüzyll Osmanl Efendisi Mustafa Ali Meva'idün-Nefa'is fi Kava'idi'lMecalis, Harvard,The Department of Near Eastern Languages \& Civilizations Harvard University.

Chebel, M. (2002): “Sexualité, pouvoir et problématique du sujet en islam”, in Confluences Méditerranée 2 (41): pp. 49-65.

Develi, H. (Ed.), (1998): XVIII. yy İstanbul'a dair Risale-i Garibe, İstanbul, Kitabevi.

El-Rouayheb, K. (2005): Before Homosexuality in the Arab-Islamic World, 15001800, Chicago, The University of Chicago Press.

Elias, N. (1978): What is sociology?, London, Hutchinson.

Elias, N. (1982): The Civilizing Process, Oxford, Blackwell.

Elias, N. (1987): "The Changing Balance of Power between the Sexes. A ProcessSociological Study: The Example of the Ancient Roman State”, in Theory, Culture \& Society 4: pp.287-316.

Erdoğan, S. N. (1996): Sexual life in Ottoman society, İstanbul, Dönence Yayınları. Imber, C. (2004): Şeriattan Kanuna Ebussuud ve Osmanli'da İslami Hukuk, İstanbul, Tarih Vakfi Yurt Yayınları. 
İnalcik, H. (1993): "State, Sovereignty and Law during the Reign of Süleyman" in H. İnalc1k and C. Kafadar (Eds.), Süleyman the Second and his time: 69-102, İstanbul, Isis Press.

Kayra, C. (Ed.), (1987): Hafiz Hizır Illyas Aga, Tarih-i Enderun. Letaif-i Enderun, İstanbul, Güneş Yayınları.

Kuru, S. S. (2000): The Scholar and Author in the $16^{\text {th }}$ century Ottoman Empire: Deli Birader and his Dafi'ül gumum ve Rafi'ül humum, Ph.D Thesis, Cambridge MA, Harvard University.

Landor, R. (Ed.), (2001): Mehmed Gazali (Deli Birader), Book of Shehzade. Dafi'ül gumum ve Rafi'ül humum, İstanbul, Dönence Yayınları.

Laqueur, T. (1992): La fabrique du sexe: essai sur le corps et le genre en Occident, Paris, Gallimard.

Malti-Douglas, F. (1991): Woman's Body, Woman's Word, Gender and Discourse in Arabo-Islamic Writing, Princeton, Princeton University Press.

Mennell, S. (2003): “Asia and Europe: Comparing Civilizing Processes”, in E. Dunning and S. Mennell (Eds.), Norbert Elias: 101-117, London, Sage Publications.

Najmabadi, A. (2005): Women with Mustaches and Men without Beards: Gender and Sexual Anxieties of Iranian Modernity, Berkeley, University of California Press.

Rubin, A. (2007): "Legal borrowing and its impact on Ottoman legal culture in the late nineteenth century" in Continuity and Change 22 (2): pp. 279-303.

Taner, T. (1999): “Tanzimat devrinde ceza hukuku”, in Tanzimat, vol. 1: 221-232, İstanbul, Milli Eğitim Bakanlığı Yayınları.

Uzel, İ. (Ed.), (2005): Tabib Mustafa Ebu'l Feyz. Tuhfetü’l Müteehhilin. Evlilik armăganı, Ankara, Kebikeç Yayınları.

Velidedeoğlu, H. V. (1968): “Türk Hukuk Hayatındaki Düalizm ve Şer’̂̂ Hukuktan Laik Hukuka Geçiş", in Yargıtayın 100. Yıldönümü Armağanı: 710-718, İstanbul, Cezaevi Matbaası.

Velidedeoğlu, H. V. (1999): "Kanunlaştırma Hareketleri ve Tanzimat", in Tanzimat, vol. 1: 139-209, İstanbul, Milli Eğitim Bakanlığı Yayınları.

Young, G. (1905): Corps de droit ottoman: recueil des codes, lois, règlements, ordonnances et actes les plus importants du droit intérieur, et d'études sur le droit coutumier de l'Empire Ottoman, vol. 2, Oxford, Clarendon Press.

Young, G. (1906): Corps de droit ottoman: recueil des codes, lois, règlements, ordonnances et actes les plus importants du droit intérieur, et d'études sur le droit coutumier de l'Empire Ottoman, vol. 7, Oxford, Clarendon Press.

Ze'evi, D. (2006): Producing Desire. Changing sexual discourse in the Ottoman Middle East 1500-1900, Berkeley, University of California Press. 